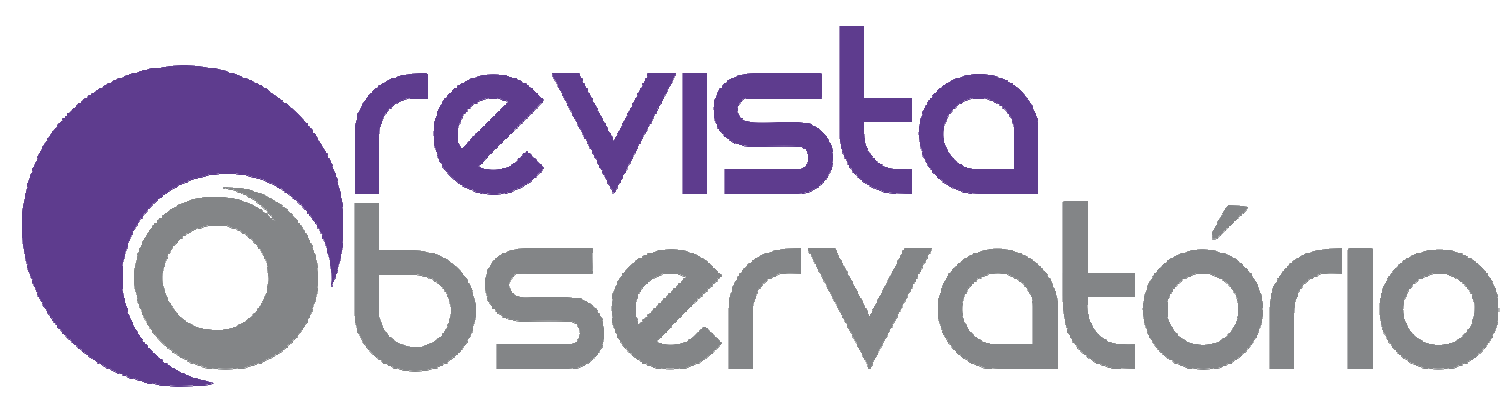

ISSN n² 2447-4266

Vol. 4, n. 5, agosto. 2018

DOI: http://dx.doi.org/10.20873/uft.2447-4266.2018v4n5p536

\section{BENEFÍCIOS PEDAGÓGICOS DO USO DE EQUIPAMENTOS CELULARES EM SALA DE AULA}

PEDAGOGICAL BENEFITS OF THE USE OF CELLULAR EQUIPMENT IN CLASSROOM

BENEFICIOS PEDAGÓGICOS DEL USO DE EQUIPOS MÓVILES CELULARES EN EL AULA

\author{
Jocyléia Santana dos Santos ${ }^{1}$ \\ Erisnalva Pereira da Silva ${ }^{2}$ \\ Isabel Auler Cristina Pereira ${ }^{3,4}$
}

\title{
RESUMO
}

A utilização do telefone celular em sala de aula tem alcançado visibilidade diante de seu inadequado uso, que gera insatisfação tanto nos professores e equipe envolvida no órgão institucional quanto dos alunos. Em consideração a essa conjuntura a proposta da Aprendizagem Significativa vai ao encontro da necessidade apresentada através de uma dinâmica interacional que sugestiona um adequado uso do aparelho eletrônico. O presente artigo visa propostas de execução dos princípios contidos na teoria de Ausubel e Vygotsky. Foi

\footnotetext{
${ }^{1}$ Doutorado em História (UFPE), Mestrado em História (UFPE), Graduação em Historia (PUC GOIÁS). Professora e Coordenadora do Programa de Pós-Graduação em Educação (PPGE-UFT)Email: jocyleia@uft.edu.br.

${ }^{2}$ Graduação em Letras e Pedagogia (UNITINS). Mestranda em Educação pela Universidade Federal do Tocantins (UFT). E-mail: erisnalva.silva@ifto.edu.br.

${ }^{3}$ (In Memorian) Doutora em Educação pela Universidade Federal da Bahia (UFBA). Mestre em Literatura Brasileira pela UnB, (2002). Graduação em Letras Inglês/Português, Reitora da Universidade Federal do Tocantins 2016-7. Professora do Programa de Pós-Graduação em Educação (PPGE-UFT). E-mail: isabel@uft.edu.br.

${ }^{4}$ Endereço de contato das autoras (por correio): Universidade Federal do Tocantins (UFT), Programa de Pós-Graduação em Educação. Câmpus de Palmas Avenida NS 15, Quadra 109 Norte, Plano Diretor Norte Bloco III, Sala 24 Palmas/TO, CEP: 77001-090, Brasil.
} 


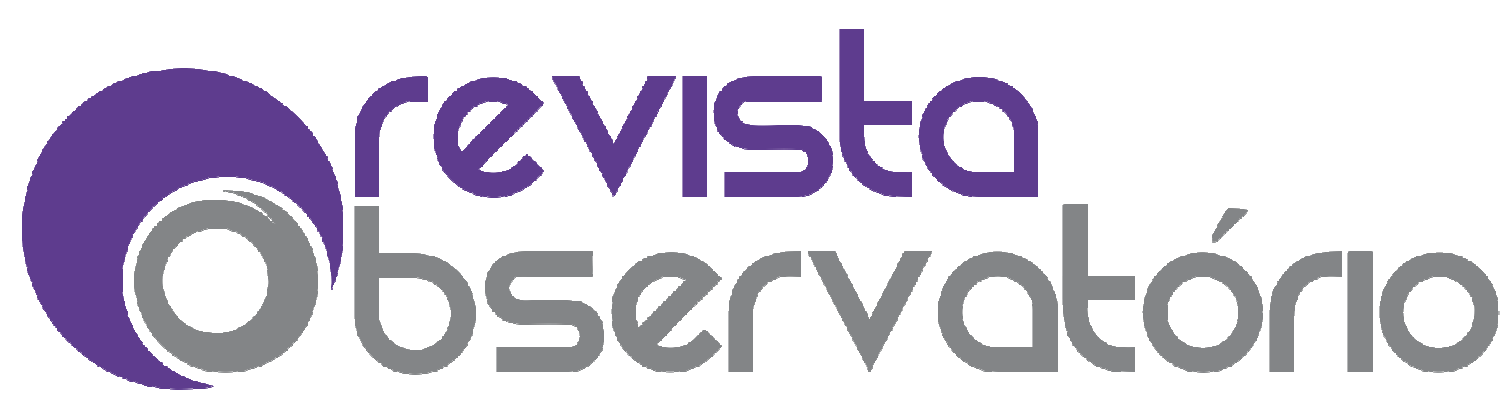

ISSN n² 2447-4266

Vol. 4, n. 5, agosto. 2018

DOI: http://dx.doi.org/10.20873/uft.2447-4266.2018v4n5p536

constatado que os professores, depois de conscientizados, buscaram métodos além do estímulo-resposta. No entanto, barreiras como a não-estimulação da autonomia obtida na formação precisam ser superadas.

PALAVRAS-CHAVE: Telefone celular; aprendizagem significativa; estrutura cognitiva; representação social.

\section{ABSTRACT}

The use of the cell phone in the classroom has achieved visibility in face of its inadequate use, which generates dissatisfaction both in the teachers and staff involved in the institutional body and the students. In consideration of this conjuncture, the proposal of Significant Learning meets the need presented through an interactional dynamics that suggests an adequate use of the electronic device. This article proposes proposals for the implementation of the principles contained in the theory of Ausubel and Vygotsky. It was seen that teachers, after becoming aware, sought methods other than stimulus-response. However, barriers such as non-stimulation of autonomy obtained in training need to be overcome.

KEYWORDS: Cell phone; meaningful learning; cognitive structure; social representation.

\section{RESUMEN}

La utilización del teléfono móvil en el aula ha alcanzado visibilidad ante su inadecuado uso, que genera insatisfacción tanto en los profesores y en el equipo involucrado en el órgano institucional cómo en los alumnos. En consideración a esa coyuntura la propuesta del Aprendizaje Significativo va al encuentro de la necesidad presentada a través de una dinámica interaccional que sugiere un adecuado uso del aparato electrónico. El presente artículo tiene por objeto propuestas de aplicación de los principios contenidos en la teoría de Ausubel y Vygotsky. Se constató que los profesores, después de tomar conciencia, buscaron 


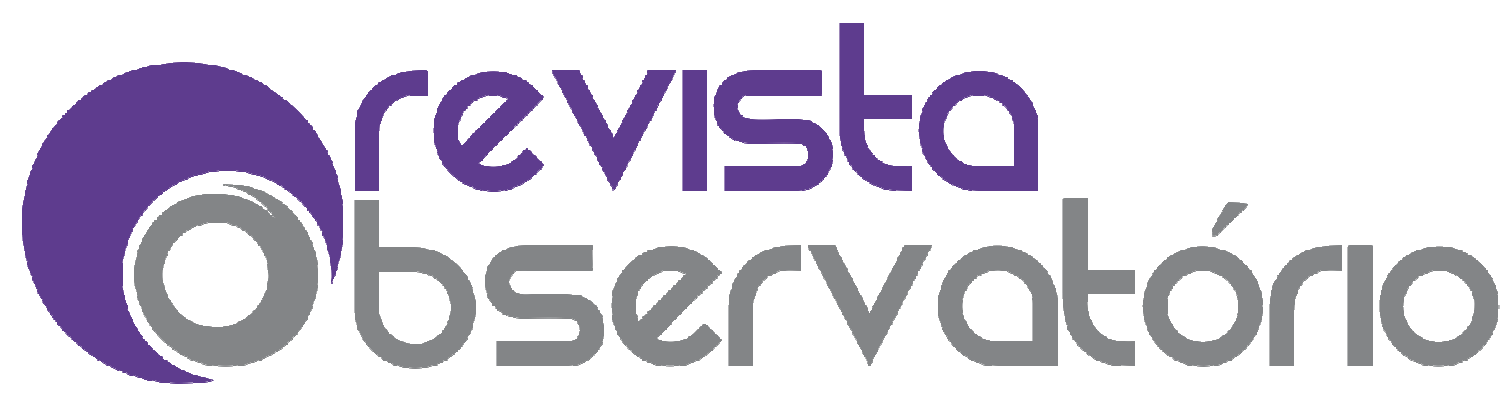

ISSN n² 2447-4266

Vol. 4, n. 5, agosto. 2018

DOI: http://dx.doi.org/10.20873/uft.2447-4266.2018v4n5p536

métodos más allá del estímulo-respuesta. Sin embargo, barreras como la noestimulación de la autonomía obtenida en la formación necesitan ser superadas.

PALABRAS CLAVE: Teléfono móvil; aprendizaje significativo; estructura cognitiva; representación social.

Recebido em: 02.03.2017. Aceito em: 19.06.2018. Publicado em: 01.08.2018. 


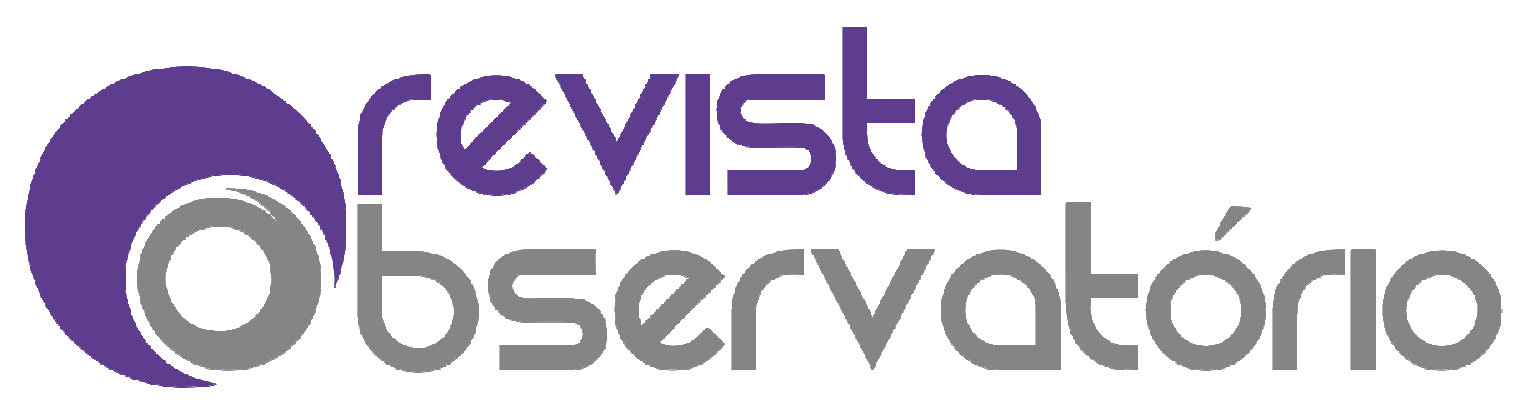

ISSN n² 2447-4266

Vol. 4, n. 5, agosto. 2018

DOI: http://dx.doi.org/10.20873/uft.2447-4266.2018v4n5p536

\section{Introdução}

A Constituição Federal, na Lei da Educação traz a seguinte afirmação:

Art. 205. A educação, direito de todos e dever do Estado e da família, será promovida e incentivada com a colaboração da sociedade, visando ao pleno desenvolvimento da pessoa, seu preparo para o exercício da cidadania e sua qualificação para o trabalho (BRASIL, 1988, s/p.).

Inicialmente, algumas conceituações devem ser bem explicadas. Segundo Dicionário Aurélio, desenvolvimento consiste em: "fazer crescer; aumentar as faculdades intelectuais de; tornar claro (o obscuro); explicar (...) crescer; progredir; aumentar; propagar-se; estender-se, prolongar-se; perder $\mathrm{O}$ acanhamento". Sendo assim, torna-se possível compreender que um dos objetivos da promoção da educação baseia-se na formação de um indivíduo em constante ascensão intelectual e social, confiante na apropriação e interação entre saberes (2016 s/p.).

No que tange à conceituação de cidadania, foi explanada como o atributo de cidadão (CIDADANIA, 2017, s/p.). Cidadão, por sua vez, fala de "indivíduo no gozo dos direitos civis e políticos de um estado livre; habitante de cidade" (CIDADÃO, 2017, s/p.). Noutras palavras, a prática da cidadania só ocorre mediante a utilização/uso das garantias legitimadas pela Lei.

A qualificação para o trabalho está mais passível de simples compreensão, já que qualificar quer dizer: "Apreciar; avaliar; classificar; enobrecer; ilustrar" (QUALIFICAÇÃO, 2017, s/p.). Ou seja, um dos intuitos do acesso à educação consiste em tornar alguém mais bem reconhecido/avaliado para o mercado de trabalho. 


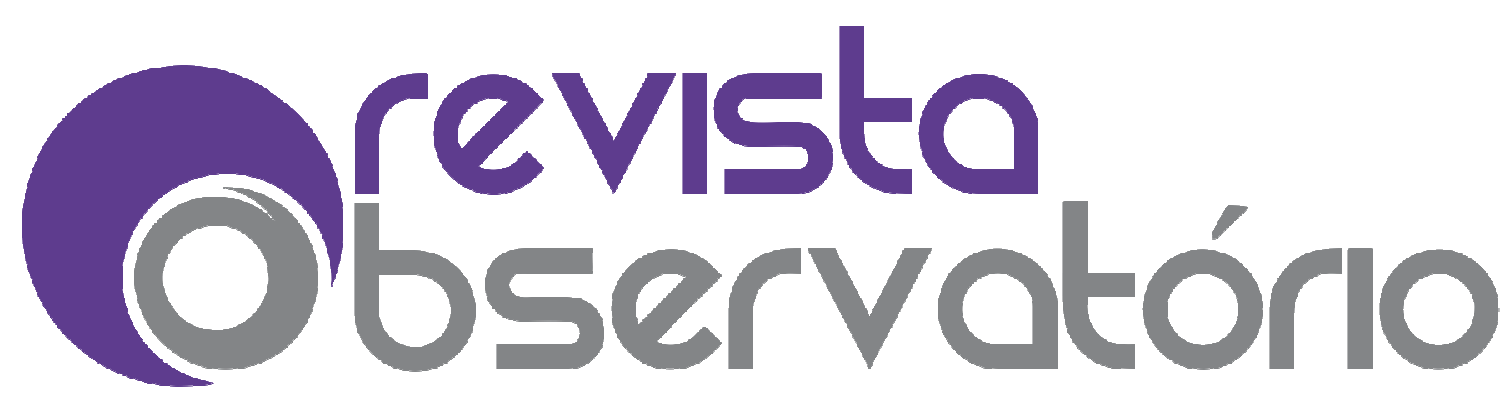

ISSN n² 2447-4266

Vol. 4, n. 5, agosto. 2018

DOI: http://dx.doi.org/10.20873/uft.2447-4266.2018v4n5p536

Dessa forma, o crescimento pessoal, execução da cidadania e boa classificação profissional precisam ocorrer para que o objetivo da educação seja cumprido de forma efetiva. Todavia, tais transformações serão mais difíceis de existir caso o aluno não compreenda a transmissão de saberes, por parte do professor, como algo significativo/relevante para a sua formação como indivíduo.

\title{
Aprendizagem Significativa e Representação Social
}

A teoria basilar consiste do presente artigo consiste na Aprendizagem Significativa, proposta por David Ausubel trazendo o conceito a seguir:

\begin{abstract}
"Aprendizagem Significativa", que "é um processo por meio do qual uma nova informação se relaciona, de maneira substantiva (não-literal) e não-arbitrária, a um aspecto relevante da estrutura cognitiva do indivíduo" (MOREIRA, 1999 p. 11 apud AUSUBEL, 1963 s/p.).
\end{abstract}

Para melhor explanação da ideia, vejamos:

Isto é, nesse processo a nova informação interage com uma estrutura de conhecimento específica, a qual Ausubel chama de "conceito subsunçor", ou, simplesmente, "subsunçor", existente na estrutura cognitiva de quem aprende (ibid. s/p.).

Quando se fala em sala de aula, somos direcionados a uma representação, que consiste no "sentido pessoal que atribuímos aos significados elaborados socialmente" (LANE, 2006, p. 46), à ideia que comumente se tem é a de que seja um lugar de um ensino formal (GARCIA, 2005). Ou seja, local onde há predominância de leis rígidas, imutáveis, dotado de um conhecimento distante e técnico.

Para Lane (loc. cit.) esse pensamento social é fundamentado a partir da institucionalização do órgão educacional. 


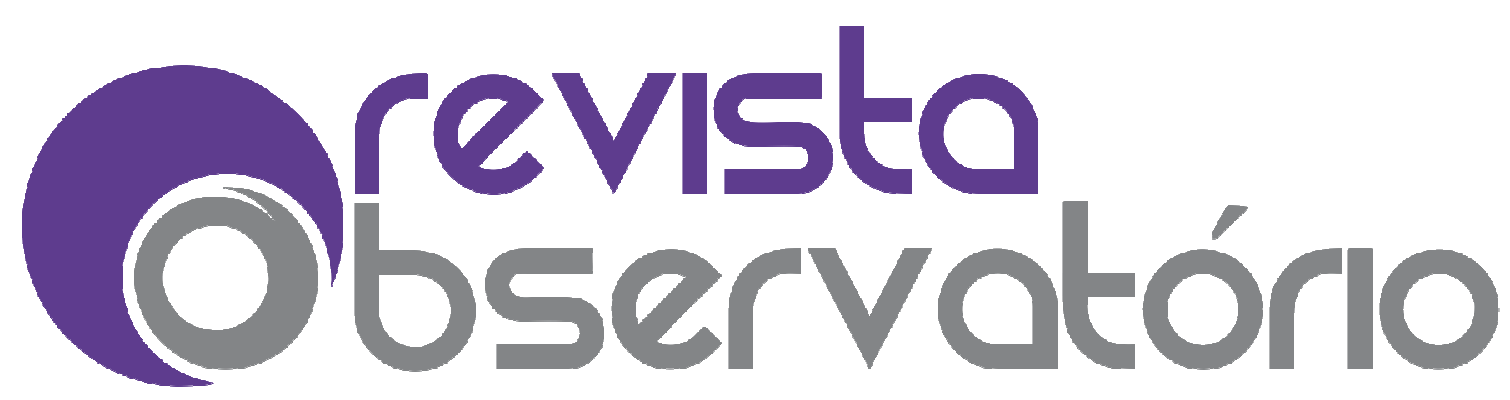

ISSN n² 2447-4266

Vol. 4, n. 5, agosto. 2018

DOI: http://dx.doi.org/10.20873/uft.2447-4266.2018v4n5p536

Da mesma forma que a família, a educação também é institucionalizada, ou seja, princípios, objetivos, conteúdos, direitos e deveres são definidos pelo governo a fim de garantir que, em todos os seus níveis, ela reproduza conhecimentos e valores (...)

Segundo Flament (1989 apud MOYSÉS, 2009, s/p.), "as representações sociais só são modificadas quando os desacordos entre elas e a realidade atingem níveis insuportáveis, ou seja, mediante profundas coerências intra ou interindividuais ". Assim, é possível inferir que a forma de pensar da sociedade, referente à percepção que se tem da escola, pode sim ser alterada.

Jodebelet (1989, p. 36 Apud MOYSÉS, 2009) considera um conceito de representação social com algumas similaridades:

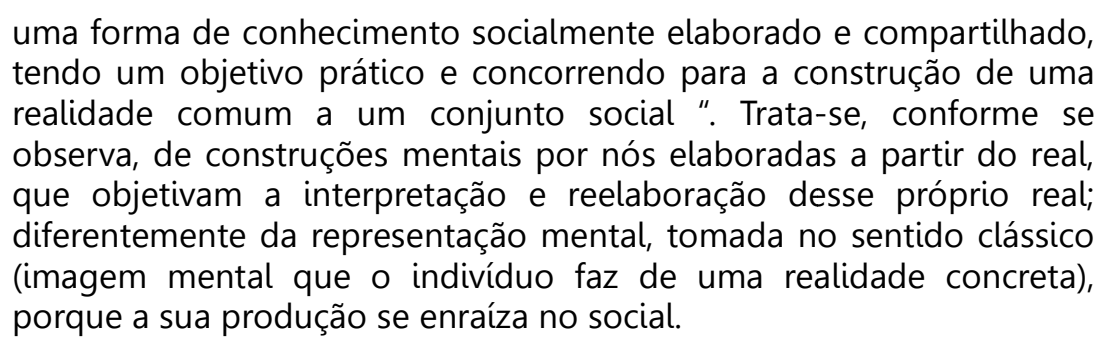

As elaborações sociais são construídas mediante as vivências grupais, a partir do contexto ambiental em que o indivíduo está inserido. Todavia, se o consenso é de que a escola seja um "lugar para aprender", o que significa aprender? Para Catania (1999, p. 21) aprendizagem pode ser definida como "uma mudança relativamente permanente no comportamento, resultante da experiencia".

\section{Relevância política e social do processo de ensino-aprendizagem}

O objetivo final é que haja aprendizado. No entanto, diante dessa conjuntura, outra questão emerge: 


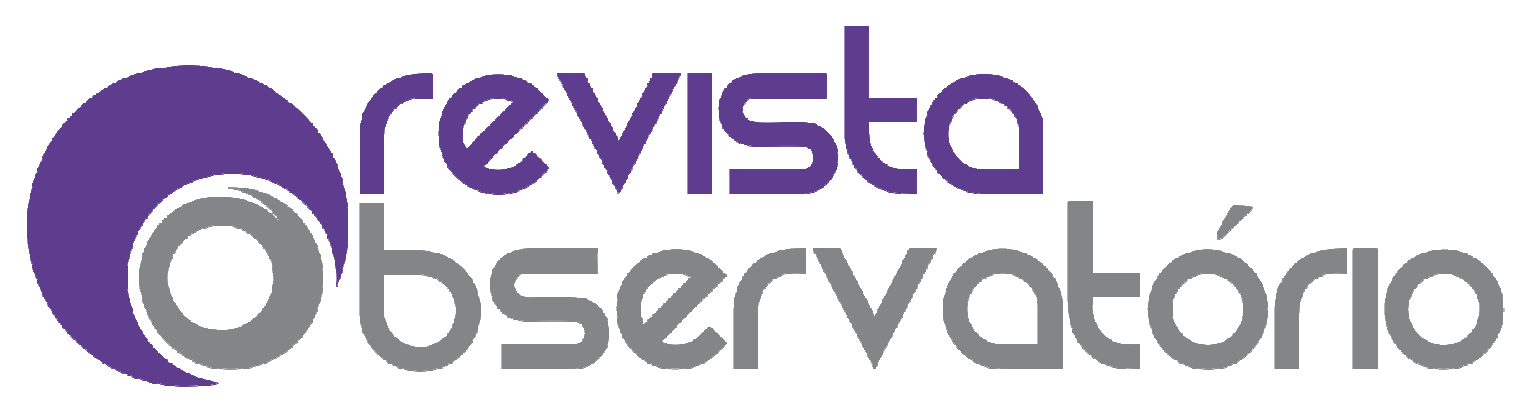

ISSN n² 2447-4266

Vol. 4, n. 5, agosto. 2018

DOI: http://dx.doi.org/10.20873/uft.2447-4266.2018v4n5p536

Ensinar o quê? Seriam todos aqueles saberes que lhes permitirão atuar no mundo em que vivem de forma crítica e consciente. Desde as habilidades básicas como saber ler, escrever, fazer as operações matemáticas, até as tecnicamente mais elaboradas, os conhecimentos sistematizados, as artes etc (MOYSÉS, 1995, p. 14).

Quando se fala em saber ensinar, vai muito além de uma habilidade técnica do professor de modo a torná-lo competente tendo em consideração o processo de ensino/aprendizagem. A complexidade está inerente a ela, é necessário organização e comprometimento; entrega e disponibilidade (MOYSÉS, 2009).

De maneira sintetizada: "é algo que se define pelo engajamento do educador com a causa democrática e se expressa pelo seu desejo de instrumentalizar política e tecnicamente o seu aluno, ajudando-o a construir-se como sujeito social " (MOYSÉS, ibid. p. 14).

Sabemos que o professor, sozinho, não é capaz de gerar mudanças no ambiente escolar e nem nas origens econômicas e sociopolíticas. No entanto, o peso da função que ele carrega, sendo profissional de educação é extremamente relevante no que tange à qualidade do ensino (MOREIRA, ibid. 1995). E o ensino, uma vez sendo melhorado, produz significativas críticas e possibilidades de avanço e/ou progresso.

Diante da conjuntura apresentada, vem à tona os seguintes questionamentos: o que é necessário fazer para que o processo "ensinoaprendizagem" seja mais efetivo? Por qual (is) motivo (s) a apropriação do conhecimento transmitido em sala de aula não tem gerado mudanças na sociedade, acréscimo aos saberes aos já existentes?

\section{Relevância do reconhecimento do saber do aluno}

Libâneo $(1985$, p.137) corrobora que: 


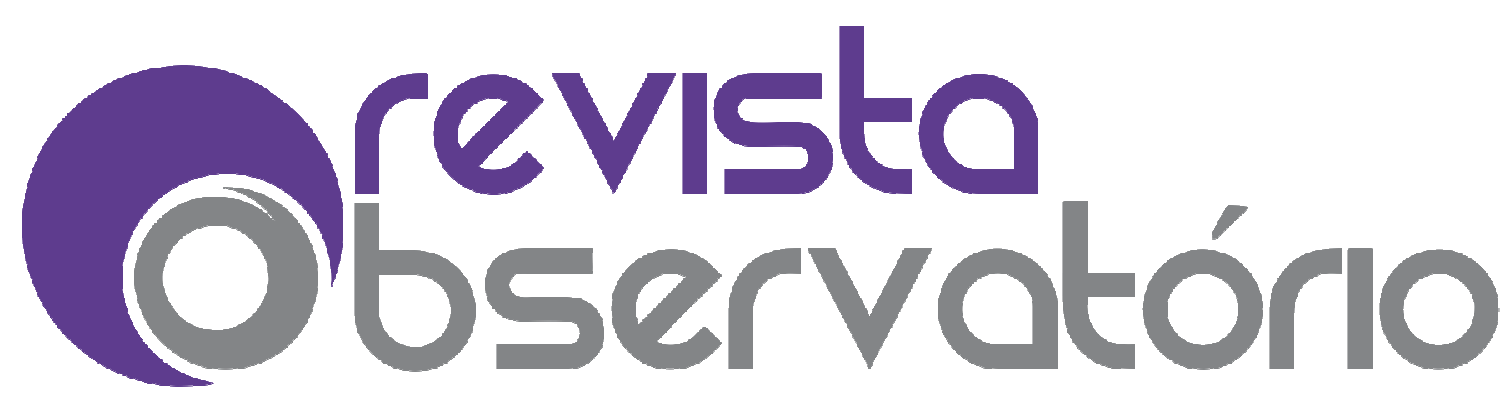

ISSN n² 2447-4266

Vol. 4, n. 5, agosto. 2018

DOI: http://dx.doi.org/10.20873/uft.2447-4266.2018v4n5p536

O trabalho docente deve ser contextualizado histórica e socialmente, isto é, articular ensino e realidade. O que significa isso? Significa perguntar, a cada momento, como é produzida a realidade humana no seu conjunto; ou seja, quais significados têm determinados conteúdos, métodos e outros eventos pedagógicos, no conjunto das relações sociais vigentes.

Assim como Freire realizou em sua metodologia de ensino com adultos, em que, a partir dos objetos e momentos experienciados pelas camadas populares, alfabetizava-os, não se deve desprezar o saber do acadêmico, gerado a partir de sua história de vida.

Dessa forma, é crucial considerar o "subsunçor" (um conceito, uma ideia, uma proposição) presente na estrutura cognitiva, pois pode servir de "'ancoradouro' a uma nova informação de modo que esta adquira, assim, significado para o sujeito (i.e., que ele tenha condições de atribuir significados a essa informação) " (MOREIRA, ibid. p. 11).

Moysés (1995) corrobora com essa perspectiva, quando afirma que o conhecimento pertencente ao aluno, se reconhecido, pode ser utilizado como facilitador (no processo de ancorador de nova informação). Segundo sua ótica, há um valor social em torno dos conhecimentos adquiridos em aula. Há, ainda, um trabalho mental que busca conciliar os antigos com os novos saberes.

\footnotetext{
O valor social da aprendizagem depende do quanto ela é significativa para o aluno. Para isso é necessária a ocorrência de vigorosa atividade psico-intelectual por parte de quem aprende, atividade essa que se divide em entre a busca incessante do sentido e a constante coordenação mental dos conhecimentos novos com os já existentes (MOYSÉS, op. cit. p. 42).
}

De acordo com Lane (op. cit., 2006) o indivíduo, por meio de seus comportamentos, influencia e é influenciado o tempo inteiro. Conforme as próprias mudanças instauradas no âmbito histórico, político, social etc. Sendo 


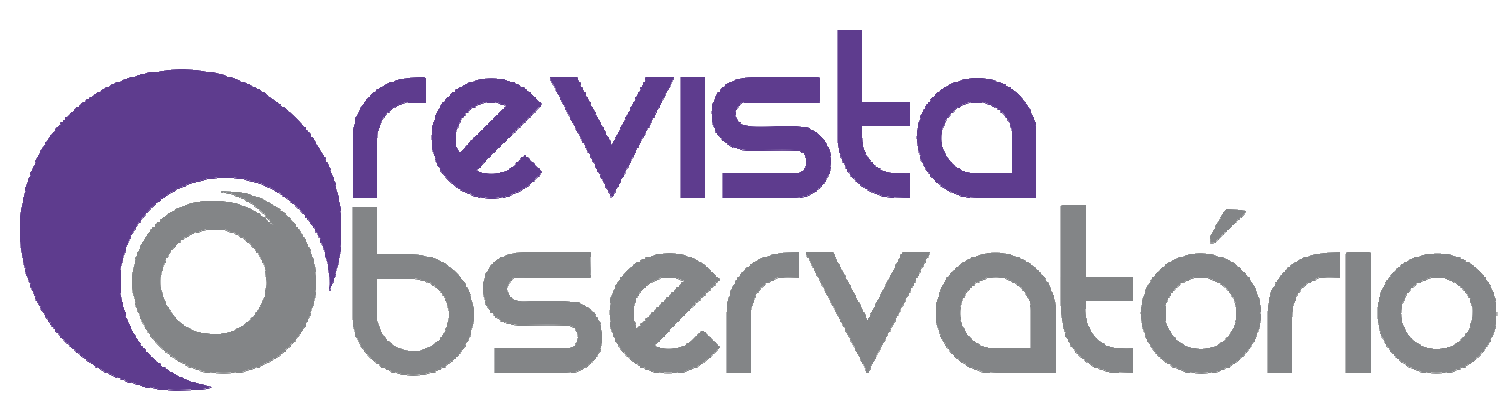

ISSN n² 2447-4266

Vol. 4, n. 5, agosto. 2018

DOI: http://dx.doi.org/10.20873/uft.2447-4266.2018v4n5p536

assim, é perceptível que o uso de tecnologias, como o computador e, mais recentemente, o celular, veio para contribuir e auxilia o processo de alteração no "cenário social na busca pela melhoria e pela facilitação da vida e das práticas dos indivíduos" (MORAES, 2007, p. 5).

O celular, ou telefone móvel, passou por diversas modificações até chegar ao que hoje conhecemos. O início de sua história se deu em 1973. Após sucessivas melhorias, chegamos ao celular que contém alguns atributos, como: câmera com alta resolução; espaço de mais de $16 \mathrm{gb}$ de memória externa etc. É chamado até de mini computador (JORDÃO, 2009).

Dentre as características peculiares a que mais se destaca é o uso da internet, principal instrumento de acesso às redes sociais, bem como a possibilidade de pesquisas e encontro de informações se utilizando de navegadores. Além disso, cabe destacar o recente fenômeno da globalização e sua influência nas formas de acessar os tipos de conhecimento e a alteração nas formas de interação interpessoal, no contato indivíduo-indivíduo.

Bauman (2009, p. 50) corrobora quando traz um olhar relevante a respeito da pressa em acessar redes sociais, não perder nenhuma oportunidade de estabelecimento de contato com o outro.

A oportunidade que cada ponto pode conter vai segui-lo até o túmulo; para aquela oportunidade única não haverá "segunda chance". Cada ponto pode ter sido vivido como um começo total e verdadeiramente novo, mas se não houve um rápido e determinado estímulo à ação instantânea, a cortina pode ter caído logo após o começo do ato, com pouca coisa acontecendo no intervalo. A demora é o serial killer das oportunidades. 


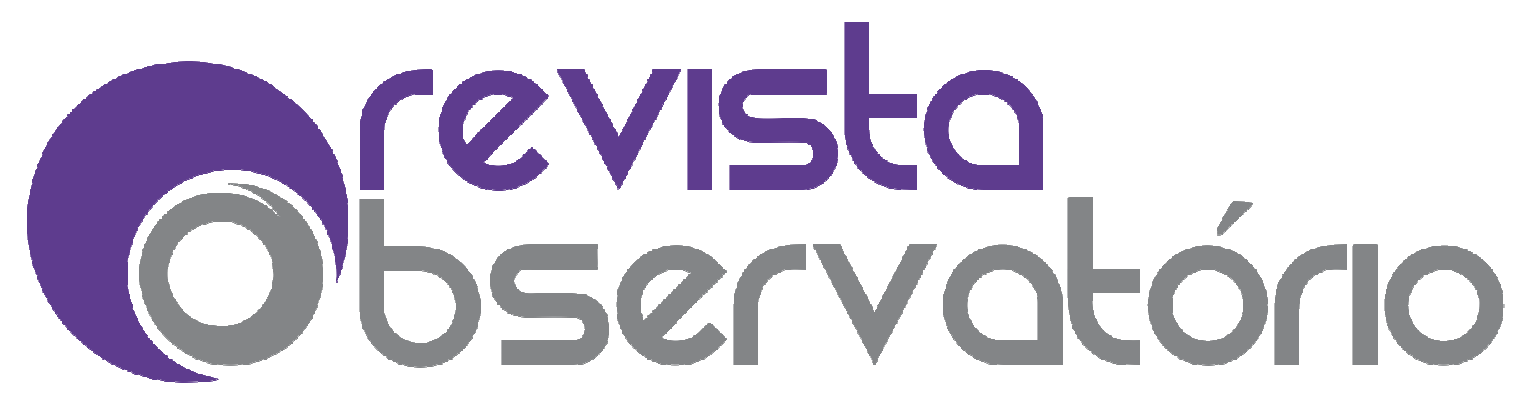

ISSN n² 2447-4266

Vol. 4, n. 5, agosto. 2018

DOI: http://dx.doi.org/10.20873/uft.2447-4266.2018v4n5p536

\section{Tipos de aprendizagem e tentativa de modelagem concomitante à saída do modelo de habitual punição}

O Tocantins, assim como outros estados, assegura, o Projeto de Lei n. ${ }^{\circ}$ $331 / 2012$ que traz diretivas proibitivas no que se refere ao uso do telefone celular em sala de aula. A principal justificativa é a de que a preservação do ambiente pedagógico precisa ser respeitada.

Uma das ações mais tomadas conforme a legislação em vigor consiste em punir, noutras palavras, caso não possua estratégias para lidar com a presente situação, faça parar de existir. O que é um equívoco que limita a utilização de diversas mídias no interior do ambiente escolar, de forma geral se despreza toda fonte de diversão ou de potencial atração ausente de aplicação didática, pois não presta para a escola (SILVA, 2012).

Ainda para Lane (op. cit. 2009) somente quando a consciência de si (desenvolvida a partir da leitura crítica diante do mundo) abrange o aspecto social é que as transformações são possíveis. Então, uma vez que há o direcionamento de como os equipamentos eletrônicos devem ser usados, bem como a contextualização com a realidade de vida do indivíduo, torna-se possível a elaboração/atribuição de explicações conceituais para eventos habituais. Atestando, portanto, a sua significância.

Como forma de complemento à questão supracitada, temos Moysés (op. cit. p. 23), que fala sobre o valor de o professor possibilitar ao aluno considerar o novo conhecimento também significativo.

É importante assinalar que esse processo (o da aprendizagem) não pode prescindir da atitude de querer aprender, por parte do aluno. Essa se expressa através de uma disposição para relacionar, de maneira consistente e coerente, à sua estrutura cognitiva o novo conhecimento, potencialmente significativo. Em outras palavras, o que queremos dizer é que não basta que o professor ache o assunto relevante e significativo. É necessário que o aluno chegue também a 


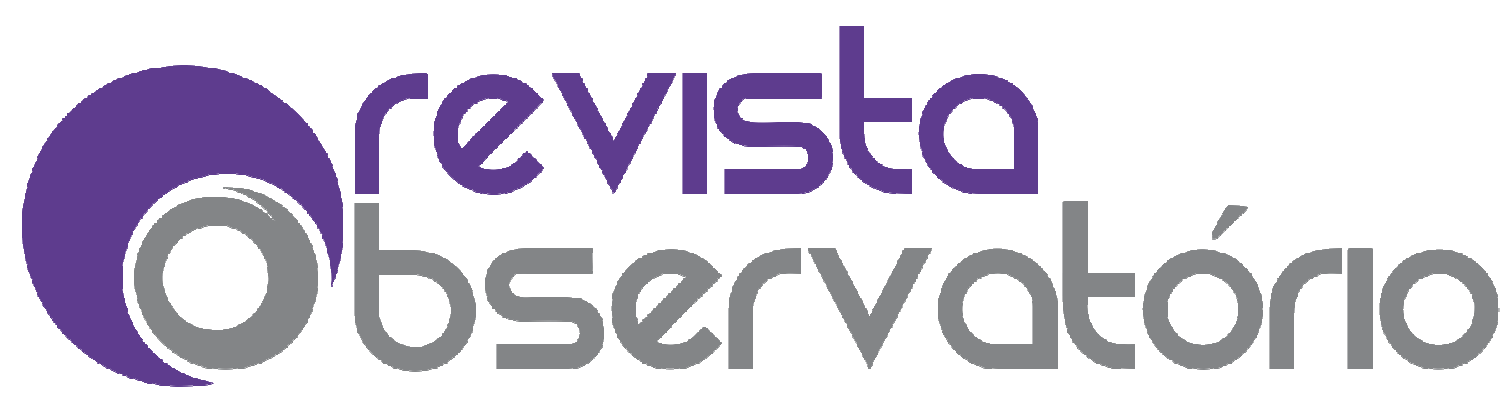

ISSN n² 2447-4266

Vol. 4, n. 5, agosto. 2018

DOI: http://dx.doi.org/10.20873/uft.2447-4266.2018v4n5p536

essa conclusão. Só assim ele estará em condições de se apropriar do conteúdo, reconstruindo-o na sua estrutura cognitiva.

No entanto, vale ressaltar que mobilizar estruturas engendradas nem sempre é tarefa simples. Já que as instituições se adaptaram a fazer/tomar decisão sempre de dada forma. Como já testificado por Lane (ibid. p. 18),

(...) este processo (o de viabilizar mudanças sociais) não é simples, pois os grupos e os papéis que os definem são cristalizados e mantidos por instituições que, pelo seu próprio caráter, estão bem aparelhadas para anular ou amenizar os questionamentos e ações de grupos, em nome da "preservação social".

Ausubel assevera a existência de duas formas de aprendizagem: aprendizagem por descoberta e aprendizagem por recepção. No primeiro caso, o aprendiz deve encontrar o resultado final de determinada problemática. No segundo, ele recebe o resultado já pronto, elaborado. Dentro da primeira modalidade existe ainda a aprendizagem por descoberta dirigida e a autônoma (MOREIRA apud AUSUBEL, loc. cit.).

Partindo desses pressupostos, a Escola poderia realizar técnicas com os estudantes, visando o alcance da resposta esperada, ou seja, o uso consciente do aparelho celular. Um exemplo a ser colocado em prática seria a modelagem comportamental. Essa é uma técnica de mudança de comportamento difundida principalmente pela Psicologia e está presente na Análise Experimental do Comportamento.

O primeiro passo para a possibilidade de compreensão da técnica está em entender o conceito de reforço positivo.

O reforço positivo (reforço porque aumenta a probabilidade de o comportamento reforçado voltar a ocorrer; positivo porque a modificação produzida no ambiente era sempre a adição de um estímulo). Por exemplo, quando o rato pressiona a barra, aparece uma gota de água em seu ambiente (MOREIRA \& MEDEIROS, 2007, p. 63). 


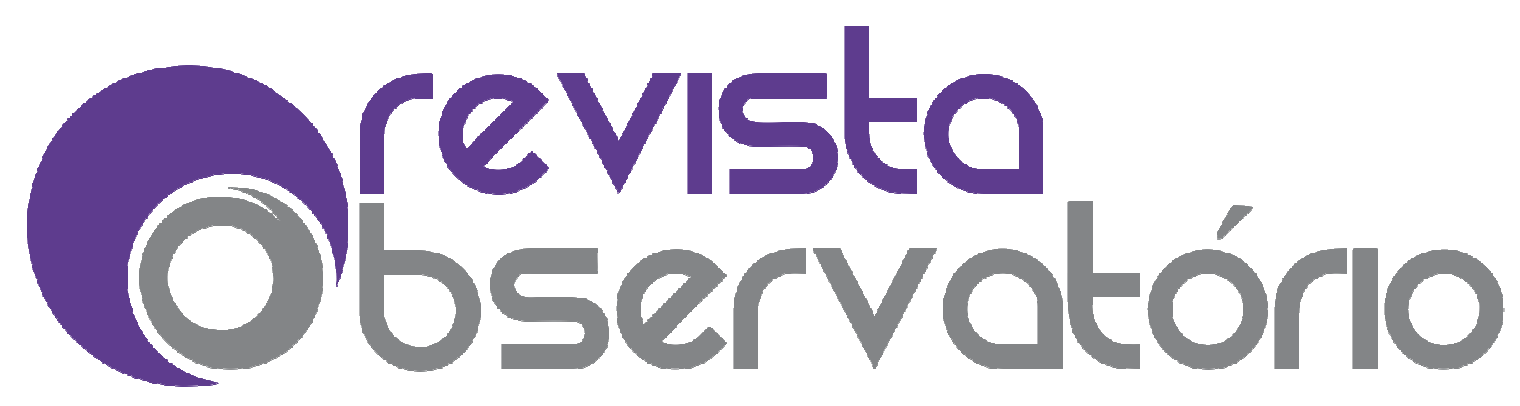

ISSN n² 2447-4266

Vol. 4, n. 5, agosto. 2018

DOI: http://dx.doi.org/10.20873/uft.2447-4266.2018v4n5p536

A técnica da modelagem é um método pelo qual, através do reforçamento positivo, instalam-se novas respostas por meio de um processo gradativo de aprendizagem tendo como objetivo um comportamento terminal. "Pais e parentes reforçam o balbuciar dos bebês, exigindo cada vez mais sequências de sons mais parecidos com os sons das palavras da língua que falam" (MOREIRA \& MEDEIROS, ibid. p. 62).

No presente caso, podemos apresentar o comportamento final (que precisa ser claro e preciso) que pretende se chegar, o qual é o aluno utilizar o equipamento eletrônico somente para fins educativos. Para isso, alguns comportamentos intermediários (aproximações sucessivas) devem ser emitidos e, posteriormente, reforçados. São eles: aluno levar o celular para a escola; ligar celular; acessar navegador; digitar palavras-chaves a respeito da temática; encontrar conteúdo satisfatório; ler em alta voz; trazer benefício ao grupo escolar; sair do navegador; guardar o celular.

Conforme a teoria, o reforço positivo então, seria o não-atrito no relacionamento aluno-professor, uma vez que a manutenção do que foi acordado permaneceria, regra de convivência que se constitui vantajosa e/ou benéfica para ambos.

\section{Estratégias para a efetivação da aprendizagem significativa}

Para a efetivação da ideia supracitada, faz-se crucial que o corpo docente invista em atividades e explanações mais dinâmicas, que exijam atividade (saída da condição passiva, de somente receptor), não desprezem as atividades realizadas pelos estudantes. Além, é claro de permitir que a mudança seja incorporada a si próprio, ou seja, que consiga vencer as possíveis resistências no que concerne às recentes transformações tecnológicas. 


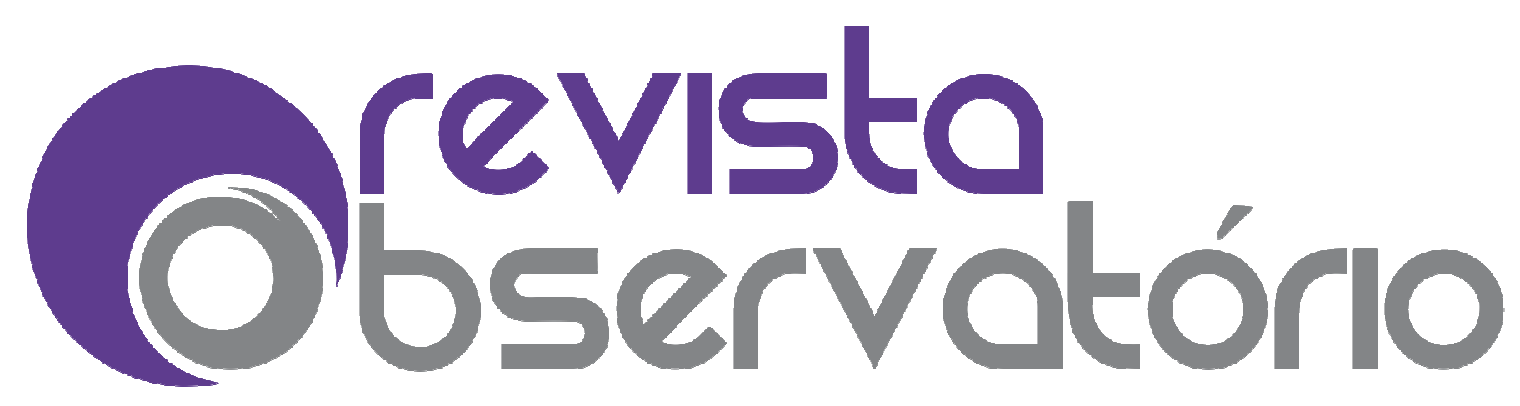

ISSN n² 2447-4266

Vol. 4, n. 5, agosto. 2018

DOI: http://dx.doi.org/10.20873/uft.2447-4266.2018v4n5p536

A discriminação é quando "o comportamento muda diante da mudança do estímulo discriminativo" (BAUM, 1999, p. 112). Dessa forma, gradativamente, o acadêmico vai aprendendo a discriminar ambientes, começando a diferenciar que não é em todos os lugares que ele pode fazer uso do aparelho celular e nem o utilizar indistintamente.

Cabe ressaltar exemplificações acerca da aprendizagem por descoberta dirigida, que possui como uma das principais características a fórmula para resolver problemas. Neste caso, o professor pode enviar e-mail para os alunos após a explicação das questões a serem resolvidas e trabalhar $\mathrm{o}$ poder/capacidade sintetizador, tendo em vista que o momento de selecionar as principais ideias e, assim, fazer generalizações, já ocorreu (MOYSÉS, op. cit..).

No que se refere à aprendizagem por descoberta autônoma, o professor pode enviar um mapa mental associado à parte mais relevante do conteúdo explanado para o e-mail de cada estudante e solicitar que resumam o que já está sintetizado em três palavras principais; pedir que estudantes desenhem uma representação do esquema; façam grupos e discutam o que poderia ser retirado da simbologia ou montem um quebra-cabeça com as figuras mais relevantes da temática apresentada; entre outros.

É importante frisar que as exemplificações citadas possuem potência significativa principalmente por estarem associadas a um objeto habitualmente usado e conhecido, o celular. Tal ressalva contribui para a diminuição da aprendizagem automática ou mecânica, que se resume a "estímulo-resposta", desprovida de relação com o conteúdo presente na estrutura cognitiva. E quando essa conexão não é feita, a resposta do aluno se torna decorar (MOYSÉS, passim). 


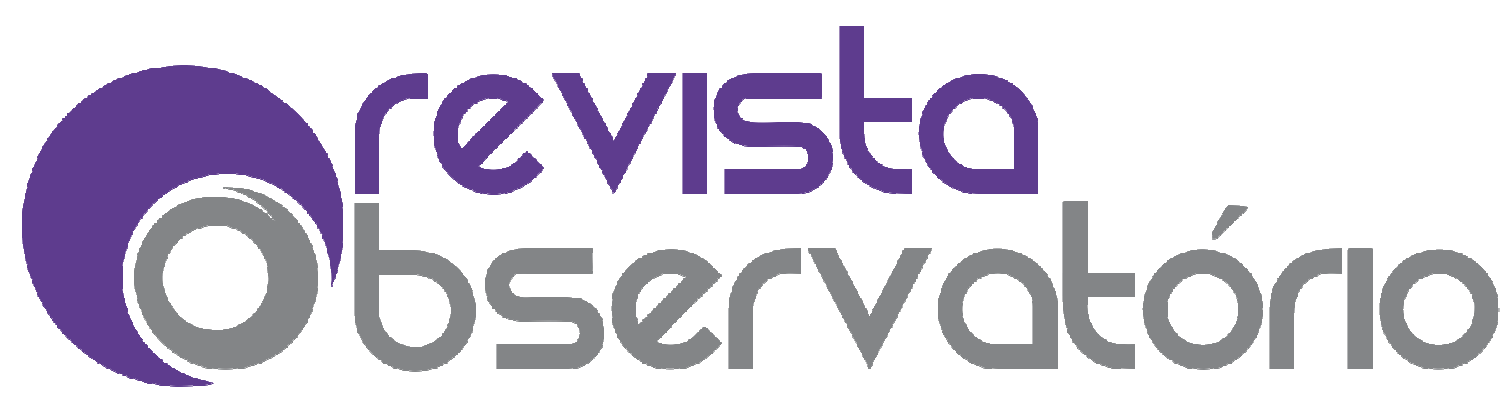

ISSN n² 2447-4266

Vol. 4, n. 5, agosto. 2018

DOI: http://dx.doi.org/10.20873/uft.2447-4266.2018v4n5p536

Para complementar a ideia supracitada, Moysés (ibid. p. 31) assegura ainda que a interação entre professor-aluno precisa ser dinâmica, a transmissão de saber precisa perpassar o rotineiro.

Formular questões, pedir exemplos, apresentar problemas de uma maneira nova, evitar a rotina, a cópia de modelos, enfim, usar recursos que levem os alunos a pensar e a trabalhar mentalmente $o$ conhecimento são exemplos de como deveria se dar essa interação.

Ainda no que se refere a formas criativas de ensino, pode-se frisar mais formas de se levar a um aprendizado significativo é trazer a compreensão de significado por meio de questionamentos. O que se torna amplamente eficaz devido à possibilidade de utilização do conhecimento já adquirido e a probabilidade de inferir novos saberes, fazendo uso do raciocínio lógico (MOYSÉS, ibidem. p. 64).

Tal discussão faz-se relevante principalmente por colocar em foco questões cotidianas que habitualmente são menosprezadas.

Mas, ao se fazer uma análise do atual contexto escolar, nota-se que
ainda são muito perceptíveis no cotidiano da escola, as reclamações e
insatisfações por parte dos professores em relação aos alunos e vice-
versa. Ou seja, a relação professor-aluno parece ser permeada por
animosidades ou conflitos. Diante de tantos desconfortos
pedagógicos, houve alguns impasses: Entender ou repreender?
Orientar ou ignorar? A partir daí, tomou-se a decisão de olhar de
frente o problema e o aproveitar para um tema de pesquisa a ser
investigado: Como a relação professor-aluno pode contribuir no
processo ensino-aprendizagem? (LOPES, 2009, p. 2)

Dentre os diversos vieses que a questão apresentada pode suscitar, podemos citar que o puro estabelecimento de regras - que tende a ser exacerbado - sem o momento mais recreativo pode soar aversivo. Por exemplo, na sala de aula da professora Rosângela ( $4^{\circ}$ série) foi acordado a respeito da execução de algumas regras de conduta. Como: 


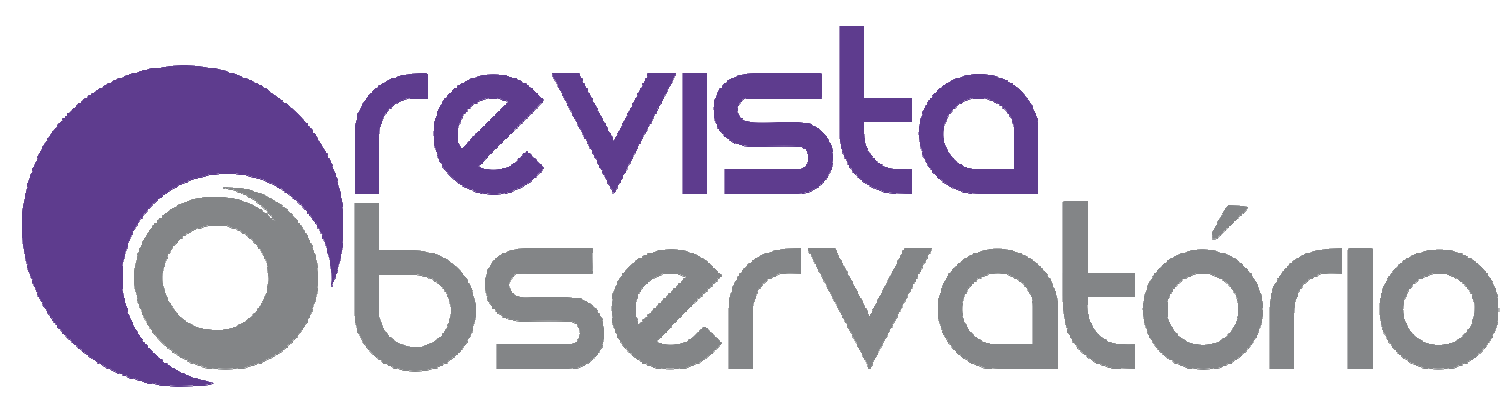

ISSN n² 2447-4266

Vol. 4, n. 5, agosto. 2018

DOI: http://dx.doi.org/10.20873/uft.2447-4266.2018v4n5p536

(...) prestar atenção à explicação, só falar em voz baixa com o colega, não andar pela sala ou dela sair durante a realização das tarefas de aula, não escrever ou ler enquanto a professora dá uma explicação de assunto novo, levantar o braço quando quiser falar ou solicitar ajuda etc (MOYSÉS, ibid. p. 74).

O curioso foi que a cogitação de que um clima de tensão ou opressão se instauraria, não se concretizou. Pelo contrário, quando os alunos terminavam suas obrigações, eram "liberados". Podiam, por um tempo, sair da aula, brincar, correr, entre outros. Exemplo de como atributos apetitivos podem trazer melhora para o ambiente escolar como um todo.

\title{
Teorias complementares
}

Vygotsky traz dois conceitos que podem reforçar o que vem sendo apresentado até o presente momento, que são: conceito espontâneo e conceito científico. Para ele, o conceito científico (sistematizado) advém de uma reconstrução do saber do conceito espontâneo (vivencial).

\begin{abstract}
Visto por esse prisma, ressalta com força absoluta o papel que a escola pode desempenhar na luta dos setores populares pela apropriação do saber culturalmente sistematizado. A forma metodológica e intencional como os conceitos científicos nela são trabalhados - ou deveriam ser - abre caminho para a revisão e melhor compreensão dos conceitos espontâneos que cada aluno traz dentro de si. Assim, refletindo o cotidiano de sua classe social, o aluno leva para a escola na forma de conceitos espontâneos certos conhecimentos e valores, dos quais vai adquirindo progressiva consciência através desse movimento. Dependendo de como isso é trabalhado, pode resultar daí uma maior lucidez por parte do aluno, das relações de força presentes na sociedade, mas que não conseguiam atingir sua compreensão (MOYSÉS, 2009, p. 28, Apud. VYGOSTKY, 1987, s/p.).
\end{abstract}

De acordo com o que o foi mostrado, podemos dizer que a explicação cognitivista da aprendizagem, na maneira compreendida por Vygostky, apresenta a possibilidade de se tornar basilar para que as minorias possam se 


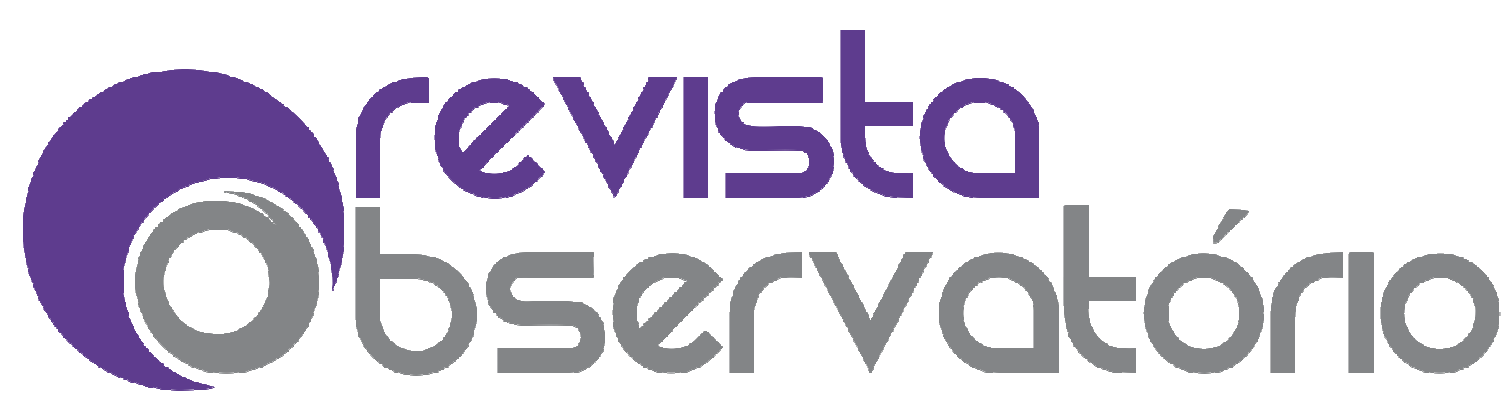

ISSN n² 2447-4266

Vol. 4, n. 5, agosto. 2018

DOI: http://dx.doi.org/10.20873/uft.2447-4266.2018v4n5p536

superar, conquistar ainda mais no quesito do saber, de transformá-los em indivíduos conscientes e não-passivos (MOYSÉS, ibid.).

Ainda quanto à estimulação do real entendimento do saber por parte do aluno,

É interessante notar que muitos dos conhecimentos que são transmitidos de forma a privilegiar a aprendizagem automática poderiam ser perfeitamente trabalhados no sentido da compreensão. Bastaria para isso que o professor procurasse se acercar do saber espontâneo de seus alunos, de sua cultura, de suas vivências e experiências anteriores (MOYSÉS, ibid. p. 30).

Cabe destacar a crítica que existe quanto à distribuição do conhecimento de forma institucionalizada, tecnicista e rígida. O que foi visualizado não só como um problema que a escola pública enfrenta, mas também nas instituições privadas. "Em suma, vale dizer que tanto nas escolas da rede pública como nas da rede privada - com raras exceções - ainda predomina o saber enciclopédico, descolado da realidade, que pouca valia tem para a construção do sujeito social" (MOYSÉS, ibid. p. 33).

\section{Desafios enfrentados pelo professor na prática da aprendizagem significativa}

Um aspecto importante que não deve ser deixado de lado é o de que, por mais que o corpo discente se preocupe com a capacidade de compreensão de determinado conteúdo, quando se fixa e sistematiza, as raízes da conexão estímulo-resposta sobrevivem. Assim, entendimento e memorização se correlacionavam (MOYSÉS, loc. cit).

Dentre as variáveis ambientais que explicam essa realidade, podemos ressaltar a necessidade de se cumprir o plano de ensino previamente estabelecido pelo MEC (Ministério da Educação) e a ausência (ou pouca) 


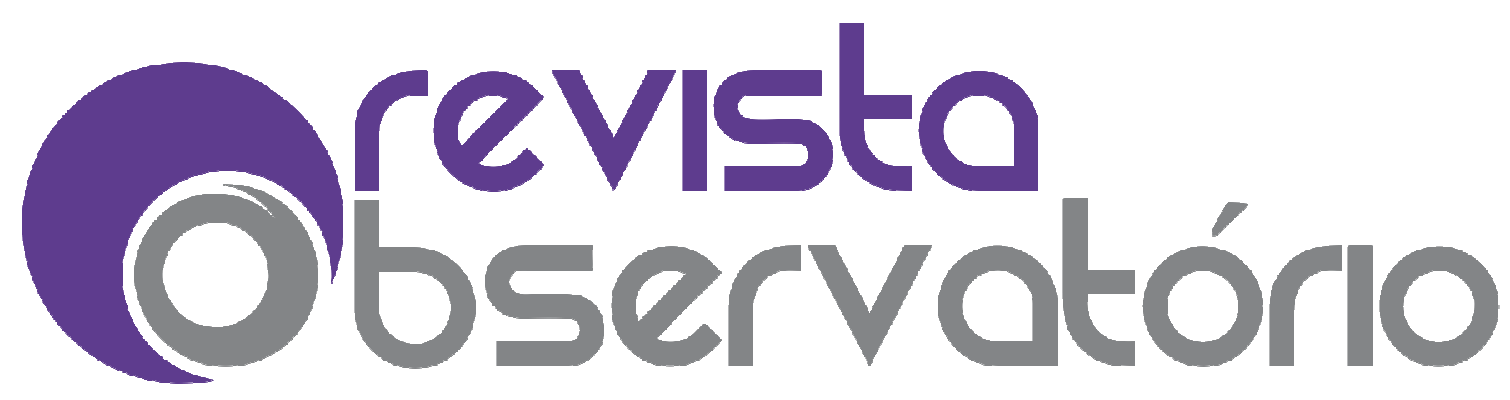

ISSN n² 2447-4266

Vol. 4, n. 5, agosto. 2018

DOI: http://dx.doi.org/10.20873/uft.2447-4266.2018v4n5p536

disponibilização de recursos - quebra-cabeças, verba para a realização de encenações teatrais, por exemplo - pela instituição de ensino.

\begin{abstract}
Entendendo que a situação é mais complexa do que a análise que dela fazemos, identificamos, contudo, aí, pelo menos dois problemas. Um deles é o hábito instalado entre os professores de utilizar exercícios já prontos nos livros didáticos ou, no caso dos que usam apenas textos, organizá-los segundo modelos apresentados naqueles livros. Sabemos que esse problema tem suas raízes no esmagamento por que vem passando a classe do magistério de $1^{\circ}$ e $2^{\circ}$ graus. $\mathrm{Na}$ falta de tempo e de recursos para ser criativo, oferecendo opções alternativas de ensino, o professor acaba apelando para os recursos que the facilitam o dia a dia, ainda que isso the cause um certo desprazer, conforme podemos constatar no decorrer da pesquisa (MOYSÉS, op. cit. p. 123).
\end{abstract}

Há ainda o fato de que muitas vezes o foco maior parece ser a formação de cunho teórico, e o de teor prático é defasado, o que pode levar a uma insatisfação enorme (tanto do discente quanto do docente), caso o profissional da educação não busque outras formas/meios/instrumentos da superação dessa circunstância.

Exemplos da ideia trazida são cursos extra, reunião com outros professores, procura de métodos utilizados por colegas de profissão que correspondeu ao que esperava, busca em livros/vários referenciais ideias que podem aplicar os princípios contidos na aprendizagem significativa, entre outros.

Não podemos nos esquecer, tampouco, que a própria escola que formou (ou deformou) a professora é, provavelmente, a mesma que não the permitiu que praticasse a autonomia e a independência. Ao contrário, a fez ser submissa às ordens. Assim, se há um forte apelo ao cumprimento dos conteúdos, ainda que estereotipados e pobres de sentido, torna-se difícil, para ela, assumir uma postura crítica diante deles. Daí a contradição: na apresentação os enriquece, os articula, buscando-lhes um sentido, mas na hora de sistematizá-los, não diferem muito da norma. São, em geral, apresentados tal qual se encontram nos livros didáticos (MOYSÉS, ibid. p. 123). 


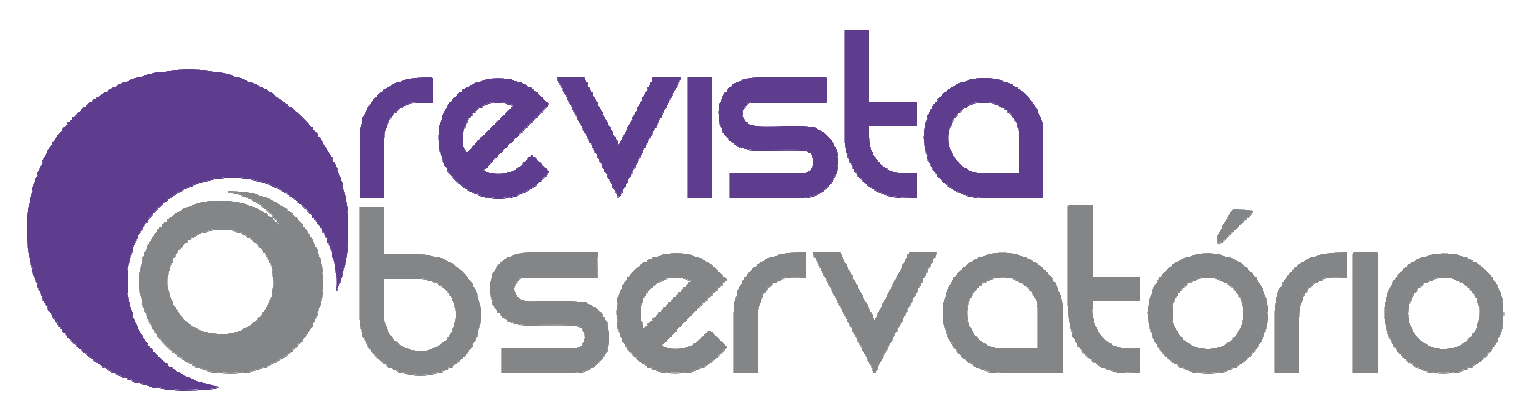

ISSN n² 2447-4266

Vol. 4, n. 5, agosto. 2018

DOI: http://dx.doi.org/10.20873/uft.2447-4266.2018v4n5p536

\section{Considerações finais}

Desta forma, vê-se que fugir um pouco do que a formação acadêmica proporcionou aos professores parece ser um processo dificultoso. Assim, cabe à Instituição de Ensino e aos professores que os mesmos facilitem o processo da aprendizagem significativa (que se contrapõe à mecânica) respeitando a direção que já lhes foi dada.

Para a efetivação exitosa de tal proposta, características como: criatividade, responsabilidade, comprometimento, disposição à mudança, motivação, empoderamento, autogestão, perseverança, percepção adequada e sensibilidade podem fazer diferença no melhoramento das atividades já prestadas.

Cabe destacar ainda que a percepção da educação como um poderoso canal de mudança social é fonte de contínua motivação, superação de obstáculos e vencimento de barreiras e, portanto, precisa estar integrada ao discurso dos profissionais de educação. As atividades elaboradas e levadas à execução precisam se mostrar como origens de motivação tanto para os alunos quanto para os professores.

E, como já citado e nas laudas anteriores e é digno de ressalva, o contínuo aperfeiçoamento profissional pode corroborar com o êxito da configuração/dinâmica de ensino exposta, explicada e detalhada, a saber: o processo de ensino mais eficaz para a transmissão e construção do saber, sendo dotado de significado.

Logo, por meio da junção de esforço e mudança de concepção, a proposta interventiva será gradualmente alcançada. E, assim, o telefone celular sairá da posição de inimigo do processo ensino-aprendizagem. 


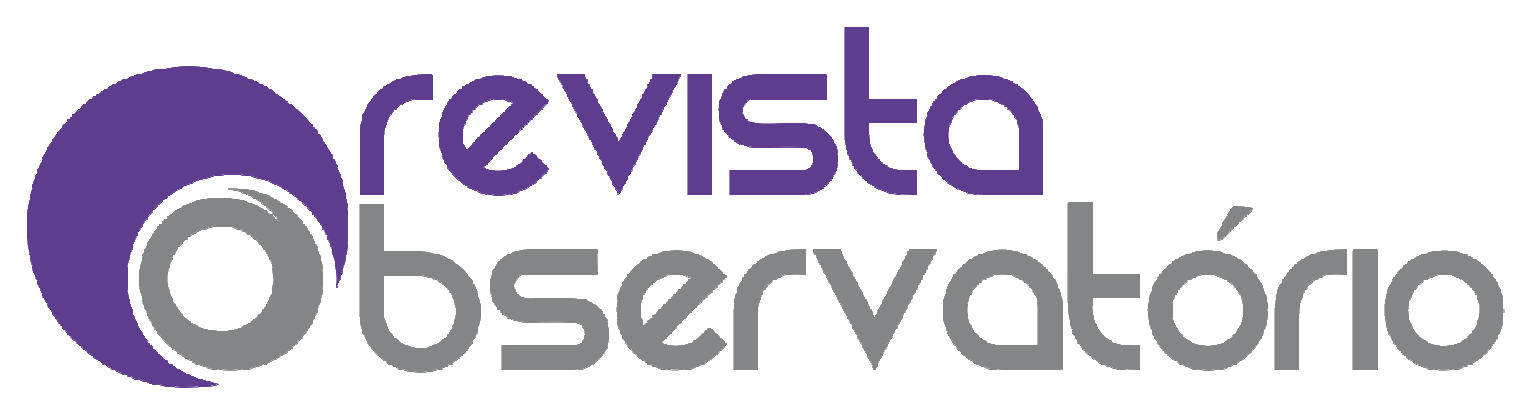

ISSN n² 2447-4266

Vol. 4, n. 5, agosto. 2018

DOI: http://dx.doi.org/10.20873/uft.2447-4266.2018v4n5p536

\section{Referências}

BAUM, W.M. Compreender o Behaviorismo. Porto Alegre: Artmed, 1999.

BAUMAN, Z. Vida para consumo. Rio de Janeiro: Jorge Hazar, 2008.

BRASIL. Constituição (1988). Constituição da República Federativa do Brasil.

Da Educação. Brasília, DF: Senado Federal: Disponível em:

<http://www.planalto.gov.br/ccivil_03/constituicao/constituicaocompilado.htm> Acesso em: 13 mar. 2017.

_. Projeto de Lei n. ${ }^{\circ}$ 331/2012. Disponível em: <http://sapl.al.to.gov.br/sapl/sapl_documentos/materia/31774_texto_integral>. Acesso em: 13 mar. 2017.

CIDADANIA. Dicionário Aurélio, 10 mar. 2017. Disponível em: <https://dicionariodoaurelio.com/cidadania>. Acesso em: 10 mar. 2017.

CIDADÃO. Dicionário Aurélio, 11 mar. 2017. Disponível em: <https://dicionariodoaurelio.com/cidadão>. Acesso em: 10 Mar. 2017.

DESENVOLVIMENTO. Dicionário Aurélio 11 mar. 2017.. Disponível em: <https://dicionariodoaurelio.com/desenvolvimento>. Acesso em: 10 mar. 2017.

QUALIFICAÇÃO. Dicionário Aurélio, 11 mar. 2017. Disponível em: <https://dicionariodoaurelio.com/qualificacao>. Acesso em: 11 mar. 2017.

CATANIA, A.C. (1999). Aprendizagem: comportamento e cognição. Porto Alegre: Artmed, 1999. 


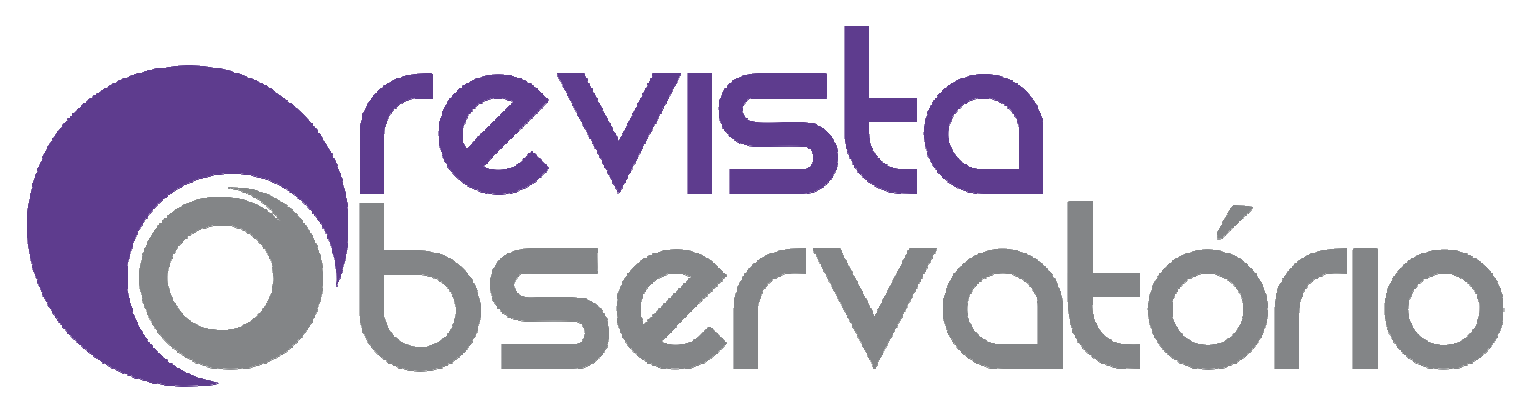

ISSN n² 2447-4266

Vol. 4, n. 5, agosto. 2018

DOI: http://dx.doi.org/10.20873/uft.2447-4266.2018v4n5p536

GARCIA, V. A. Um sobrevôo: o conceito de educação não-formal. In: PARK, M. B \& FERNANDES, R. S. Educação não-formal: contextos, percursos e sujeitos. Campinas: Unicamp/CMU, set. 2005.

JORDÃO, F. História: a evolução do celular, 22 mai. 2009. Disponível em: <https://www.tecmundo.com.br/celular/2140-historia-a-evolucao-docelular.htm>. Acesso em: 13 mar. 2017.

KOHN, K; MORAES, C H. O impacto das novas tecnologias na sociedade: conceitos e características da sociedade da informação e da sociedade digital, 2 mai. $2007 . \quad$ Disponível em: <http://www.intercom.org.br/papers/nacionais/2007/resumos/R1533-1.pdf>. Acesso em: 13 mar. 2017.

LANE, S T. M. O que é psicologia social. São Paulo: Brasiliense, 2006.

LIBÂNEO, J C. Adeus professor; Adeus professora? Novas exigências educacionais e a profissão docente. São Paulo: Cortez, 1999, p. 22

LOPES, R C S. A relação professor aluno e o processo ensino aprendizagem. $2009 . \quad$ Disponível em: <http://www.diaadiaeducacao.pr.gov.br/portals/pde/arquivos/1534-8.pdf $\geq$ Acesso em: 13 mar. 2017.

MOREIRA, M A. Aprendizagem significativa. Brasília: Universidade de Brasília, 2009. 129 p.

MOYSÉS, L. O desafio de saber ensinar. 2 ed. Rio de Janeiro: Universidade Federal Fluminense, 1995. 138 p. 


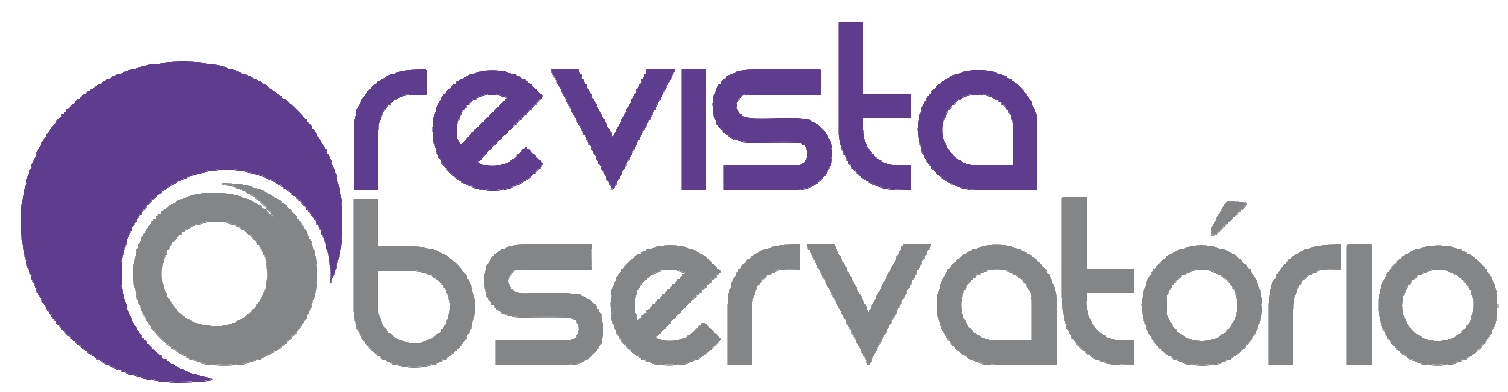

ISSN n² 2447-4266

Vol. 4, n. 5, agosto. 2018

DOI: http://dx.doi.org/10.20873/uft.2447-4266.2018v4n5p536

SILVA, M G. O uso do aparelho em sala de aula, 2012. Disponível em: <http://www2.unifap.br/midias/files/2016/04/O-USO-DO-APARELHO-CELULAREM-SALA-DE-AULA-MARLEY-GUEDES-DA-SILVA.pdf>. Acesso em: 13 mar. 2017. 